\title{
A novel approach in calculating site-specific aftercare completion criteria for landfills in The Netherlands: Policy developments
}

\author{
E. Brand (RIVM) \\ T.C.M. de Nijs (RIVM) \\ J.J. Dijkstra (ECN) \\ R.N.J. Comans (Wageningen University)
}

September 2016

ECN-W--16-021 


\title{
A novel approach in calculating site-specific aftercare completion criteria for landfills in The Netherlands: Policy developments
}

\author{
Ellen Brand $^{\mathrm{a}, *}$, Ton C.M. de Nijs ${ }^{\mathrm{a}}$, Joris J. Dijkstra ${ }^{\mathrm{b}}$, Rob N.J. Comans ${ }^{\mathrm{c}}$ \\ a National Institute for Public Health and the Environment (RIVM), PO. Box 1, 3720 BA Bilthoven, The Netherlands \\ ${ }^{\mathrm{b}}$ Energy Research Centre of the Netherlands (ECN), P.O. Box 1, 1755 ZG Petten, The Netherlands

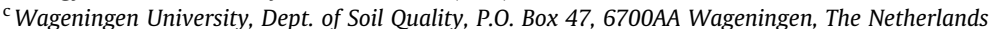

\section{A R T I C L E I N F O}

Article history:

Received 20 March 2016

Revised 26 July 2016

Accepted 26 July 2016

Available online 3 August 2016

\section{Keywords:}

Sustainable landfill management

Environmental protection criteria

MSW landfills

Risk assessment

Point of compliance

Aftercare completion

\begin{abstract}
A B S T R A C T
As part of a more circular economy, current attention on waste is shifting from landfilling towards the prevention, re-use and recycling of waste materials. Although the need for landfills is decreasing, there are many landfills around the world that are still operational or at the point of starting the aftercare period. With traditional aftercare management, these landfills require perpetual aftercare at considerable cost due to monitoring and regular maintenance of liners. In an attempt to lower these aftercare costs, and to prevent that future generations become responsible for finding a sustainable solution of present day waste, the Dutch government takes action to explore the possibilities of sustainable landfill management. A project was started to investigate whether the use of source-oriented treatment techniques (so-called active treatment) of landfills can result in a sustainable emission reduction to soil and groundwater. During the next decade, sustainable landfill management is tested at three selected pilot landfills in the Netherlands. To enable this pilot testing and to determine its success after the experimental treatment period, a new methodology and conceptual framework was developed. The aim of this paper is to describe the development of the new methodology, and in particular the policy decisions, needed to determine whether the pilot experiments will be successful. The pilot projects are considered successful when the concentrations in the leachate of the pilot landfills have sufficiently been reduced and for longer periods of time and comply with the derived site-specific Environmental Protection Criteria (EPC). In that case, aftercare can be reduced, and it can be determined whether sustainable landfill management is economically feasible for further implementation.
\end{abstract}

(c) 2016 Elsevier Ltd. All rights reserved.

\section{Introduction}

The development of a circular economy is nowadays the focus of attention in many legislative frameworks in Europe. In these legislative frameworks, waste is increasingly less considered as an end of pipe product that needs to be discarded of at a certain time. By stimulating innovation to limit the production of waste by e.g., more efficient technologies, re-use or recycling of waste, the need for landfilling is declining. Although developments towards a circular economy are to be preferred above landfilling, the need for landfills including their maintenance remains.

The fabrication of products will generate waste materials that at some point can no longer be re-used, for example due to loss of quality, or high recovery costs of the secondary material. Furthermore, currently operational landfills require proper management

\section{* Corresponding author.}

E-mail addresses: ellen.brand@rivm.nl (E. Brand), ton.de.nijs@rivm.nl (T.C.M. de Nijs),j.j.dijkstra@ecn.nl (J.J. Dijkstra), rob.comans@wur.nl (R.N.J. Comans). and future aftercare, as do landfills that are already in the process of aftercare. The management of current and future landfills should preferably be in line with the concept of environmental sustainability, and the environmental impact of a landfill on soil and groundwater should be minimized as much as possible. In the traditional aftercare of landfills, it is mandatory to seal the landfill completely with bottom, top and side liners to prevent any water from entering the landfill. This approach is generally adequate with regard to environmental protection, but is not considered sustainable. Under these conditions, the composition of the waste inside the landfill remains largely unchanged over time, as natural degradation processes are minimized. Furthermore, this containment is very costly due to everlasting monitoring and liner maintenance (i.e. the replacement of the liners at regular intervals because of their limited lifespan). Landfills that are completely sealed, present a continuing threat to the environment if not properly managed. The traditional way of landfill management thus transfers the responsibility of present day waste to future generations at high costs. 
In order to overcome the afore mentioned problems a project entitled 'Introduction of Sustainable Landfill management' (ISL) was launched in The Netherlands in 2010. This project has recently lead to a so called 'Green Deal', a unique cooperation between the National government, competent authorities, research institutes and the landfill operators. In October 2015 the 'Green Deal' was signed by the Ministry of Infrastructure and Environment of the Dutch national government, the Dutch Sustainable Landfill Foundation and landfill operators. The aim of this deal is to test at three selected existing landfills (hereafter 'pilot landfills') whether the use of source-oriented treatment techniques (so-called active treatment) can result in a sustainable emission reduction to soil and groundwater. National policy frameworks were not considered adequate to enable the rather "unconventional" pilot experiments, therefore current national legislation was extended. The aim of this manuscript is to describe the development of a new methodology, and in particular the policy decisions, needed to determine whether the pilot experiments will be successful after the period of active treatment has ended.

In the methodology that is developed and explained in this manuscript, the pilot projects are considered successful when the concentrations in the leachate of the pilot landfills have sufficiently been reduced to protect (ground) water quality. In that case, the use of protective top liners and their costly replacement may no longer be necessary, while monitoring can be reduced. When successful, the landfill operators determine whether sustainable landfill management is economically feasible for further implementation. The active treatment at the three pilot landfills will start from 2016 onwards, and is expected to take 10-12 years.

In short, the purpose of active treatment is to stimulate natural attenuation processes in the pilot landfills by controlled aeration, irrigation and the recirculation of water through the waste package, in order to wash out soluble substances (e.g. chloride and ammonium), degrade organic substances (e.g. PAH's and VOX) and immobilize metal contaminants. This treatment is contrary to conventional landfills that are completely sealed, where anaerobic processes dominate and attenuation processes proceed much slower. Research on active treatment has been performed previously by Reinhart (1996), Ritzkowski et al. (2006), Rich et al. (2008).

For the experiments only those landfills are selected that contain waste that has sufficient potential for stabilization. Landfills with certain types of hazardous waste (as indicated in international and national acceptance criteria for landfilling of waste (Min VROM, 1997; EC, 2003)) were excluded from the selection of pilot landfills. The presence of a bottom liner with a sufficient life span (liners have to be functional for the duration of the experiment), expected limited emissions to the air (landfill gases) and the economic feasibility were further important criteria when selecting suitable landfills for the pilot experiments. The landfills that were selected for the pilot study were: Site 1: Braambergen in Almere, Site 2: Kragge II in Bergen op Zoom, and Site 3: Wieringermeer in Middenmeer. The selected compartments at these landfills contain waste dominated by inorganic materials such as contaminated soil and soil purification residue (Site 1), domestic waste (Site 2), and industrial-, building- and demolition-waste (Site 3), respectively The selected landfills have been operational for 2-3 decades and are now closed for further waste acceptance (Kattenberg and Heimovaara, 2011; Kattenberg et al. 2013; Van Vossen and Heyer, 2009). For site-specific characteristics on the selected pilot landfills is referred to Brand et al. (2014), provided in the supplementary information.

Emissions suh as landfill gas (existing of mostly methane $\left(\mathrm{CH}_{4}\right)$ and carbon dioxide $\left(\mathrm{CO}_{2}\right)$ ) are excluded from the Green Deal (Kattenberg and Heimovaara, 2011) and are not part of the methodology. Also, in the long term, emissions of landfill gas are expected to become insignificant relative to leachate emissions (Laner 2011; Laner et al., 2012a,b), in particular after introduction of active aeration.

\section{Establishing reference framework and Environmental Protection Criteria (EPC)}

Below will be explained how the methodology was developed to calculate site-specific Environmental Protection Criteria (EPC), with the focus on the necessary policy decisions. The EPC are expressed as maximum concentrations $(\mu \mathrm{g} / \mathrm{l})$ of designated contaminants in the landfill leachate, in such a way that groundwater quality is protected for a certain assessment period (500 years, see Section 2.2.3) after the period of active treatment has ended. Previous studies to determine completion criteria were performed by amongst others Stegmann et al. (2006), Morris and Barlaz (2010), Laner (2011) and Laner et al. (2012a,b). Unique aspects of the methodology described in this paper is that the EPC are site specific (versus generic criteria in existing policies such as the EU Landfill Directive), the role of state-of-the-art geochemical models in the establishment of the site-specific EPC (as further explained in Dijkstra et al., 2016) versus the conventional approach based on generic linear Kd values (Hjelmar et al., 2001), and that it is the first time that aftercare completion criteria are implemented in national policy. Therefore, the methodology and criteria had to be accepted by the National government, politicians, the competent authorities and the general public.

In particular, the "competent authorities" (which are the provinces that have the legal authority to approve or disprove the outcomes, and which carry the costs of the after-care of landfills) had to be convinced that the potential positive results outweigh the potential environmental and financial risks of this experiment, and that sufficient precautionary measures are taken. For this reason, a careful balance was maintained between generic (policy based) criteria and the use of site-specific factors to develop the methodology for derivation of the EPC. The generic criteria mostly apply to the conceptual model of the landfill, and are conservative by nature. These criteria are motivated by current policy and regulatory frameworks, and the general acceptance of these frameworks in practice. The site-specific factors are of a more technical nature and of relevance for modelling and evaluation purposes. Previous studies have stressed the importance of a site-specific approach in the evaluation of the required aftercare of landfills (e.g., Morris and Barlaz 2010; Laner 2011). This paper will address specifically the policy related aspects of the derived methodology and the results, whilst the paper of Dijkstra et al. (2016) will elaborate on the scientific and technical aspects of the geochemical modelling.

\subsection{Choices based on policy context}

The EU and national regulatory frameworks set the boundary requirements regarding the derivation of EPC, acceptance criteria for waste, as well as the allowed impact on soil and groundwater quality. In Fig. 1, an overview of the relevant European and national frameworks is presented.

\subsubsection{Conceptual model to derive EPC}

The conceptual model that was adopted to derive the EPC is schematically shown in Fig. 2. This model is based on the framework of the European Groundwater Directive (GWD) (EC, 2006, 2009), European Landfill Directive (ELD) (EC, 1999) and the proposed acceptance criteria for landfilling of the DHI in Denmark (Miljøstyrelsen, 2003). A similar conceptual model was previously developed in the leaching studies of the reuse of building materials 


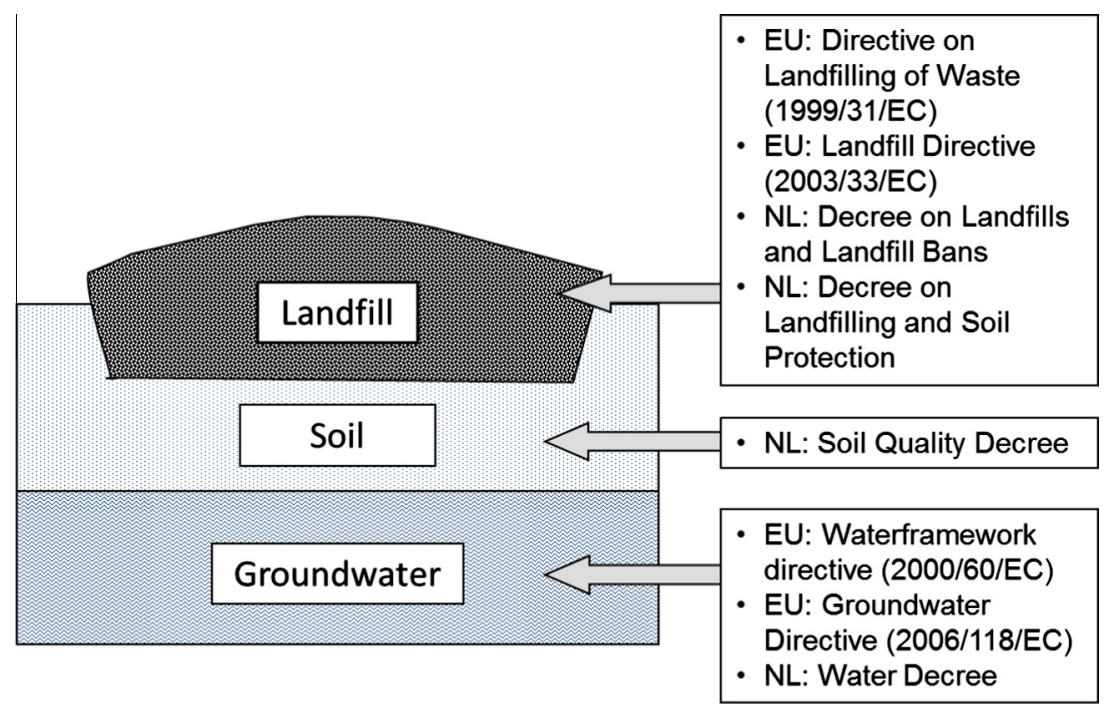

Fig. 1. Relevant European and national frameworks that play a role in the landfilling of waste.

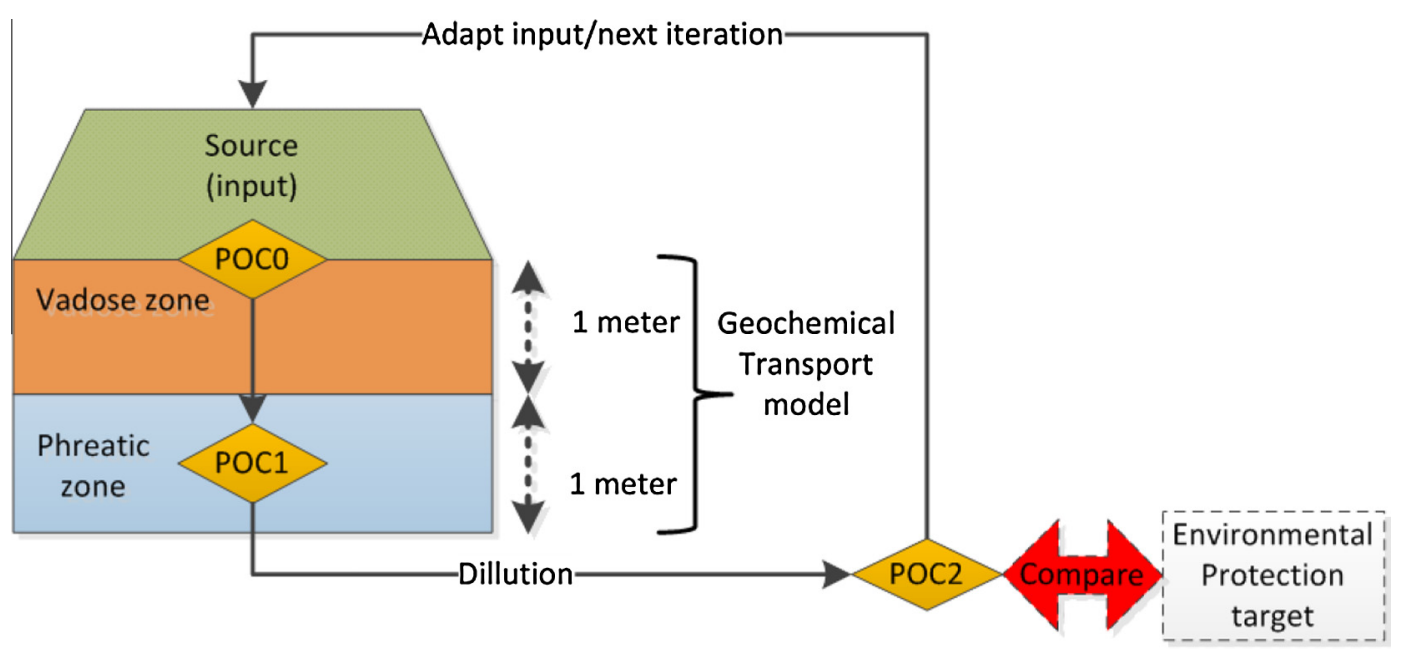

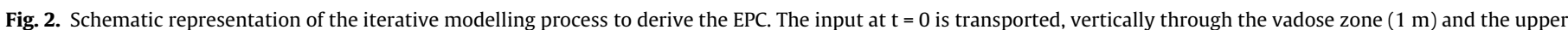

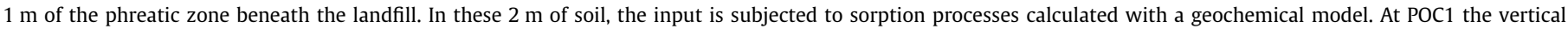

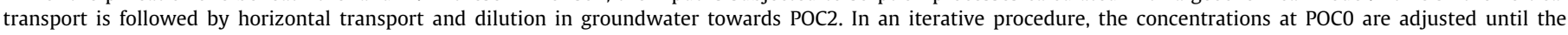
concentrations at POC2 comply with the protection targets.

in the Netherlands (Verschoor et al., 2006, 2008; Susset and Grathwohl 2010; Dijkstra et al., 2013b) and the studies of Laner (2011) and Laner et al. (2012a,b).

The conceptual model consists of several Points Of Compliance (POC) within a 'source-pathway-receptor' approach in which the landfill is the designated 'source' (Brand et al., 2014; Dijkstra et al., 2013a). In total three POC's are considered:

POCO is located in the leachate drains within the landfills and functions as the control point during the period of active treatment, because it allows for easy access to the leachate. Monitoring at this point implies that, in case the existing bottom liner would deteriorate, adequate action can be taken before the leachate can disperse in groundwater. POCO will also serve as the final assessment point at the end of the period of active treatment. However, POCO cannot directly be related to the effects of substances in groundwater. In agreement with the European Landfill Directive (EC, 1999) and the proposed acceptance criteria for landfilling of the DHI in Denmark (Miljøstyrelsen, 2003), a second POC was located at $20 \mathrm{~m}$ downstream from the landfill in the groundwater, the so-called POC2. POC2 represents the 'Receptor' and therefore represents the protection target. It is at this point that future concentrations in groundwater have to comply with legislation. Because monitoring of the leachate concentrations takes place at POCO, the protection target at POC2 is transferred into a concentration at POCO via backwards modelling. This was done using a state-of-the-art geochemical transport model which is further described in Brand et al. (2014) and Dijkstra et al. (2016). The $20 \mathrm{~m}$ distance between POCO and POC2 is the 'pathway' that the leachate will travel. The leachate is assumed to leach vertically from the landfill directly into the vadose zone (thickness $1 \mathrm{~m}$ ) before entering the phreatic zone. In the vadose zone and the upper meter of the phreatic zone (i.e., in total $2 \mathrm{~m}$ ), sorption processes are assumed to take place (see Section 2.2.2 and for details in Dijkstra et al., 2016). Thereafter, the leachate will travel horizontally in the groundwater towards POC2 and will be subjected to dilution (see Section 2.2.3 and for details in Dijkstra et al., 2016). This pathway is applied to all pilot landfills disregarding the fact that local groundwater depth might be different. This choice was made to be consistent with the defined pathway in previous regulatory frameworks regarding emission criteria for the reuse of building materials in the Netherlands 
(Verschoor et al., 2006, 2008). Another POC (POC1) is situated in the pathway between POCO and POC2, and is located $2 \mathrm{~m}$ below the landfill in the upper meter of the phreatic zone (as shown in Fig. 2). The location of POC 1 originates from the Dutch soil quality decree (Verschoor et al., 2006), and has no function other than it marks the transition point between the vertical transport of leachate from the landfill and the horizontal transport in the groundwater in the modelling of the EPC.

\subsubsection{Environmental objective}

Because emissions of landfill gas are expected to become insignificant relative to leachate emissions, the main risk during and after the experiment consists of soil and groundwater pollution due to leachate release from the landfills. Although modern landfills are generally fitted with a bottom liner, this liner will deteriorate over time and ultimately fail. As such, the groundwater system next to the landfill became the protection target and regulation on groundwater protection was adapted (Ministry of I\&E, 2011, 2013). The EPC takes into account the groundwater quality criteria for the production of drinking water as well as possible negative effects on ecosystems. For each designated contaminant, the most stringent of both targets (drinking water or ecosystems) leads to the final protection target.

The protection targets used at POC2 correspond with the Dutch drinking water standards or the HC5 (Hazardous concentration). The HC5 stands for the concentration at which 95\% of the aquatic species experience no adverse effects. These HC5 are derived by means of laboratory toxicity data and are widely accepted and used in the Netherlands for the risk assessment of soil and groundwater contamination (Verbruggen et al., 2001). For inorganic compounds (such as metals), natural background concentrations are added to this HC5, i.e. the local background concentrations in groundwater at the landfill site. Inorganic compounds occur naturally in the environment and, in correspondence with the Dutch regulatory framework on soil contamination, the effect of these naturally occurring concentrations on the ecosystem is not taken into account in the risk assessment.

Macro-parameters (such as chloride and ammonium) are also compared against the HC5 value. However, in the case that the locally occurring background concentrations exceed the HC5, the protection target becomes equal to this background concentration. In that case, the acceptable leachate concentrations can be equal to the natural background concentration at the site. This is especially relevant for landfills that are located close to brackish or saline areas, where chloride concentrations are naturally higher.

Organic contaminants are generally of anthropogenic origin and therefore a background concentration is not included in their protection target. Furthermore, elevated concentrations of organic compounds are principally not desired by Dutch law, therefore the HC5 value is divided by a factor of 100 (HC5/100) to ensure a negligible risk (Verbruggen et al., 2001; Verschoor and Swartjes 2008). This means that the protection target for organic compounds is much stricter than for inorganic compounds and macro-parameters.

\subsubsection{Relevant contaminants}

Based on the legislative framework (Min VROM 1993) a number of "generic" compounds were identified, while additional contaminants were determined for each selected landfill separately by consulting the landfill permit. In total 43 contaminants were deemed relevant to determine the EPC (see also Table 1).

- Metals (As, Cd, Cr, Cu, Pb, Hg, Ni and Zn);

- Macroparameters $\left(\mathrm{NH}_{4}^{+}, \mathrm{Cl}^{-}\right.$, and $\left.\mathrm{SO}_{4}^{2-}\right)$;

- Organic contaminants (PAH, VOX and Sum mineral oils EC10EC40).
The additional compounds selected based on the landfill permits included:

- bicarbonate;

- BTEX;

- phenols;

- cyanide.

The site-specific approach in which the EPC are derived enables expansion of this list so that it becomes suitable to other landfills if necessary. However, the availability of environmental protection targets and chemical properties of the (additional) contaminants are a prerequisite for making this method of deriving EPC applicable to all types of landfills.

\subsection{Choices in the approach to derive EPC}

The actual modelling of EPC involves many assumptions and site- specific input and was performed with a state-of-the-art geochemical transport model (Dijkstra et al., 2004, 2009) implemented in the model framework Orchestra (Meeussen 2003). This model was also used previously to derive the emission limit values for the re-use of building materials in the Netherlands (Verschoor et al., 2006, 2008). Because the model approach to derive EPC is of a rather technical nature we refer to our separate paper for details Dijkstra et al. (2016) and Brand et al., 2014. In short, the EPC are maximum concentrations $(\mu \mathrm{g} / \mathrm{l})$ in the source (landfill leachate) that are calculated in such a way that concentrations in the groundwater at POC2 do not exceed the groundwater quality criteria during the assessment period between 0 (directly after the active treatment period) and 500 years. EPC are sitespecific, due to the implementation of site-specific soil properties influencing the transport velocity of the contaminants, and due to site-specific dilution factors. When such information is available, the approach can also be used for other landfills. Because the sorption of contaminants in non-linear, the procedure to calculate EPC is an iterative process (Dijkstra et al., 2016). Next to these site-specific characteristics, some generic assumptions and choices were necessary, as further outlined below. Fig. 2 presents a schematic overview of the process to calculate the EPC.

\subsubsection{Source term}

With respect to the amount of leachate entering the vadose zone directly below the landfill, a constant net infiltration of $300 \mathrm{~mm} /$ year over the full surface of the landfill (compartment) is assumed. The $300 \mathrm{~mm} /$ year corresponds to the average net precipitation in The Netherlands, and implies that once the active treatment period ends $(T=0)$ the protective bottom liners completely fail. In reality, this infiltration will be much lower, because bottom liners are still functional during the period of active treatment. However, the assessment period is 500 years (see Section 2.2.3) and starts after the active treatment phase. It seems plausible that during this long period the liner functionality will gradually decrease, in such a way that the duration of failure might dominate the duration of functioning. Field data on the rate of liner deterioration are still lacking and for this reason Laner et al. (2012b) studied three different scenarios (intact, slow degradation and complete degradation) to highlight the differences in modelled leachate emissions. These authors concluded that any assumptions regarding the deterioration rates of liners are highly speculative. Therefore, assuming complete failure of the liners and a constant infiltration rate of $300 \mathrm{~mm} / \mathrm{y}$ is considered an acceptable worstcase assumption to derive EPC.

Concentrations are assumed to be constant as a function of time for the assessment period of 500 years (see Section 2.2.3), based on 
the worst-case assumption that a generally large waste body will lead to small temporal changes in leachate concentration (see Dijkstra et al., 2016 for the sensitivity of the calculated EPC for this assumption).

\subsubsection{Sorption, retardation and natural attenuation processes}

Sorption or retardation of contaminants to soil particles is considered only in the vadose zone and in the upper meter of the phreatic zone directly underneath the landfill (at POC1). Between POC1 and POC2 sorption and retardation of contaminants to soil particles is not accounted for, and only site-specific dilution of the contaminants in groundwater is included in the modelling. This assumption is conservative by nature, as it is likely that sorption and retardation do take place over the full $20 \mathrm{~m}$ of the pathway. In reality, the transport of contaminants in the direction of POC2 will therefore be slower. The modelling of sorption and retardation processes requires site-specific geochemical properties, particularly $\mathrm{pH}$ and the type and capacity of reactive organic and mineral surfaces that can bind the contaminants (Dijkstra et al., 2016). Below a depth of $2 \mathrm{~m}$ this information is generally not sufficiently available and difficult to estimate due to the heterogeneity of the soil and the local hydrology (Brand et al., 2014). In addition, insight in, and modellingof, anaerobic geochemical processes that control the retardation of the (full range of) designated contaminants in the saturated zone was considered to be insufficiently developed to include in the modelling approach. Under anaerobic conditions, transport of a range of metals may be further slowed down due to the precipitation of metal sulphides. The transport of certain oxyanions such as arsenic may be accelerated under these conditions, due to the dissolution of iron phases to which these compounds may bind (see also Dijkstra et al., 2016).

For similar reasons the natural degradation of organic contaminants is not considered in the modelling. Studies of Christensen et al. $(1994,2000)$ support the fact that natural degradation takes place in the leachate plume of landfills. However, Christensen et al. (2000) conclude that specific knowledge on the conditions under the landfill that are required to allow natural degradation to take place, and quantitative evidence that natural degradation plays a substantial role in the leachate plume, are still limited and difficult to obtain due to high research costs. These limitations make it difficult to quantitatively predict natural degradation at a specific site (Christensen et al., 2000). Furthermore, it is expected that the degradation of organic contaminants will take place largely in the landfill during the period of active treatment. After completion of the treatment phase, high concentrations of organic contaminants are no longer expected in the leachate and the contribution of degradation to the natural attenuation of the remaining organic contaminants is expected to be small. Together with the fact that the EPC have to comply with current regulations on soil and groundwater protection in the Netherlands, and be accepted by the competent authorities and the general public, consideration of non-validated processes to predict the natural attention, sorption and retardation of contaminants was not desired. Therefore, the worst-case assumptions described above were made instead.

\subsubsection{Dilution in the phreatic zone and assessment period}

To determine the dilution between POC1 and POC2, a sitespecific dilution factor is estimated for each landfill. The dilution factor is estimated based on the hydrological properties such as the geometry of the landfill, the thickness and porosity of the aquifer, and the difference in hydrostatic potential in the phreatic zone (Brand et al., 2014 (also in supplementary information); Dijkstra et al., 2016). In this site-specific dilution factor, the naturally occurring background concentrations in the local groundwater are taken into account.
A generic assumption is that dilution is assumed to be at stationary state, and full mixing takes place over the entire thickness of the (landfill specific) phreatic zone. In other words, the leachate disperses uniformly and instantly over the first aquifer towards POC2. In the short term, this assumption overestimates the dilution of leachate in groundwater, however in the long term, and as the bottom liner fails, this assumption becomes more realistic. This assumption is further supported by the fact that the phreatic zones of the pilot landfills are relatively shallow with a maximum of $10 \mathrm{~m}$ and that the assessment period was set at 500 years after completion of the active treatment. Within this period, full mixing of leachate over the first aquifer can be achieved.

The assessment period of 500 years, starting after the treatment phase, was selected primarily because (1) landfills have a long life span and are in general not removed and (2) landfills have a relatively thick waste layer (around 10-30 m) that can cause emissions over long periods of time. Studies of Verschoor et al. (2006) and Laner et al. (2012b) support the need for such a long assessment period in similar modelling scenarios.

The sensitivity of the modelled output (i.e. the calculated EPC values) to these choices is presented in Dijkstra et al. (2016).

\section{Results and discussion}

The final output of the modelling resulted in a list of EPC for each of the individual pilot landfills (Table 1). Each landfill thus has its own site-specific list based on the local soil and landfill properties. The modelled EPC are not the final values formalized in legislation, but were subject to further adjustment depending on public acceptability and technical feasibility. The most relevant adjustments are further discussed below.

For lead, the modelled output resulted in a very high EPC, due to predicted strong binding and retardation of this metal in the soil. Although concentrations in the leachate would not reach POC2 according to the modelling, and therefore would not pose a problem to comply with regulatory frameworks, the effects that these values can have on public perception of the experiment were reason for policy makers to lower the final EPC (to $130 \mu \mathrm{g} / \mathrm{L}$ ) for both landfills. The choice to lower the EPC to $130 \mu \mathrm{g} / \mathrm{L}$ was based on the results for the pilot 1 landfill, for which it a more acceptable value was derived.

Some of the proposed EPC are expected to be unachievable according to the landfill operators, as was the case for ammonium. Reported concentrations for ammonium in the landfill leachates of the selected pilot landfills range currently between 500 and $1500 \mathrm{mg} / \mathrm{L}$. For two of the landfills the modelled EPC values were relatively low with 1.1 and $1.8 \mathrm{mg} / \mathrm{l}$ respectively (Table 1 ). Even with elaborated measures taken by the landfill operators to reduce the concentrations of ammonium in the leachate, the possible reduction might not be enough to reach concentrations as low as the modelled values. Because the potential overall environmental gains of sustainable landfill management can outweigh the possible negative effects of elevated levels of ammonium in groundwater, it was decided by policy makers that an elevated emission for ammonium up to $50 \mathrm{mg} / \mathrm{L}$ is tolerated (Table 1). The values are, however, only tolerated under specific requirements that ensure the protection of vulnerable receptors such as surface waters, infiltration areas for drinking water and protected nature areas. For an elaborate description of these considerations and requirements, we refer to Brand et al. (2014). To increase public acceptance, the general approach to the development of the EPC and the policy-based adjustments and requirements were approved by the Dutch Soil Protection Technical Committee (TCB) an independent scientific committee providing recommendations on technical and scientific aspects of soil policy. 
Table 1

Modelling results (EPC values) for metals, macroparameters and organic compounds for three pilot landfills. Compounds marked with an ' $*$ ' required special attention and between brackets policy-based adjusted values are presented. For the underlying modelling details, see also Dijkstra et al. (2016).

\begin{tabular}{|c|c|c|c|}
\hline Compounds & $\begin{array}{l}\text { EPC Pilot } 1 \\
\text { Braambergen }\end{array}$ & $\begin{array}{l}\text { EPC Pilot } 2 \\
\text { Kragge }\end{array}$ & $\begin{array}{l}\text { EPC Pilot } 3 \\
\text { Wieringermeer }\end{array}$ \\
\hline \multicolumn{4}{|c|}{ Inorganic parameters $(\mu \mathrm{g} / \mathrm{L})$} \\
\hline Arsenic & 190 & 100 & 190 \\
\hline Cadmium & 6.4 & 3.6 & 1.3 \\
\hline Chromium & 210 & 140 & 37 \\
\hline Copper & 50 & 64 & 19 \\
\hline Mercury & 5.8 & 4.1 & 1 \\
\hline Lead & $\begin{array}{l}60,000^{*} / \\
(130)\end{array}$ & 130 & $25,000^{*} /(130)$ \\
\hline Nickel & 21 & 47 & 21 \\
\hline Zinc & 160 & 120 & 39 \\
\hline Free cyanides & 61 & 6.8 & 35 \\
\hline \multicolumn{4}{|l|}{ Macroparameters (mg/L) } \\
\hline Ammonium & $1.8^{*} /(50)$ & $1.1^{*}(50)$ & 50 \\
\hline Chloride & 450 & 160 & 2400 \\
\hline Sulphate & 700 & 200 & 1400 \\
\hline \multicolumn{4}{|c|}{ Organic contaminants $(\mu \mathrm{g} / \mathrm{L})$} \\
\hline $\begin{array}{l}\text { Mineral oil } \\
\text { sum EC10-EC40 }\end{array}$ & 470 & 270 & 100 \\
\hline \multicolumn{4}{|l|}{ VOX } \\
\hline Vinyl chloride & $0.047^{*} /(0.2)$ & $0.014^{*} /(0.2)$ & $0.01^{*} /(0.2)$ \\
\hline Dichloromethane & $0.047^{*} /(0.2)$ & $0.014 * /(0.2)$ & $0.01 * /(0.2)$ \\
\hline 1,1 dichloroethane & 4.7 & 1.4 & 1 \\
\hline 1,2 dichloroethane & 14 & 4.1 & 3 \\
\hline 1,1 dichloroethene & $0.047^{*} /(0.1)$ & $0.014 /(0.1)$ & $0.01 /(0.1)$ \\
\hline $\begin{array}{l}\text { 1,2 dichloroethene } \\
\text { (cis,trans) }\end{array}$ & $0.047^{*} /(0.1)$ & $0.014 /(0.1)$ & $0.01 /(0.1)$ \\
\hline Dichloropropane $(1,2)$ & 3.8 & 1.1 & 0.8 \\
\hline Dichloropropane $(1,3)$ & 3.8 & 1.1 & 0.8 \\
\hline $\begin{array}{l}\text { Trichloromethane } \\
\text { (chloroform) }\end{array}$ & 4.7 & 1.4 & 1 \\
\hline $1,1,1$ trichloroethane & $0.047^{*} /(0.1)$ & $0.014^{*} /(0.1)$ & $0.01^{*} /(0.1)$ \\
\hline $1,1,2$ trichloroethane & $0.047^{*} /(0.1)$ & $0.014^{*} /(0.1)$ & $0.01 * /(0.1)$ \\
\hline Trichloroethene (tri) & 47 & 14 & 10 \\
\hline Tetrachloromethane (tetra) & $0.047^{*} /(0.1)$ & $0.014^{*} /(0.1)$ & $0.01^{*} /(0.1)$ \\
\hline Tetrachloroethene (per) & $0.047^{*} /(0.1)$ & $0.014^{*} /(0.1)$ & $0.01^{*} /(0.1)$ \\
\hline \multicolumn{4}{|l|}{ PAH } \\
\hline Naftalene & $0.047 * /(0.05)$ & $\begin{array}{l}0.014^{*} / \\
(0.05)\end{array}$ & $0.01 * /(0.05)$ \\
\hline Phenanthrene & 0.028 & 0.016 & $0.006 * /(0.01)$ \\
\hline Anthracene & $\begin{array}{l}0.0066^{*} / \\
(0.01)\end{array}$ & $\begin{array}{l}0.0038^{*} / \\
(0.01)\end{array}$ & $0.0014^{*} /(0.01)$ \\
\hline Fluoranthene & 0.056 & $\begin{array}{l}0.033^{*} / \\
(0.01)\end{array}$ & $0.006 * /(0.01)$ \\
\hline Chrysene & 0.056 & $\begin{array}{l}0.033^{*} / \\
(0.01)\end{array}$ & $0.006^{*} /(0.01)$ \\
\hline Benzo(a)anthracene & $\begin{array}{l}0.0019 * / \\
(0.01)\end{array}$ & $\begin{array}{l}0.0011^{*} / \\
(0.01)\end{array}$ & $0.0002 * /(0.01)$ \\
\hline Benzo(a)pyrene & $\begin{array}{l}0.0094^{*} / \\
(0.01)\end{array}$ & $\begin{array}{l}0.0054^{*} / \\
(0.01)\end{array}$ & $0.001 * /(0.01)$ \\
\hline Benzo(k)-fluoranthene & $\begin{array}{l}0.0075^{*} / \\
(0.01)\end{array}$ & $\begin{array}{l}0.0044^{*} / \\
(0.01)\end{array}$ & $0.0008^{*} /(0.01)$ \\
\hline Indeno( $1,2,3 \mathrm{~cd})$-pyrene & $\begin{array}{l}0.0075^{*} / \\
(0.01)\end{array}$ & $\begin{array}{l}0.0044^{*} / \\
(0.01)\end{array}$ & $0.0008^{*} /(0.01)$ \\
\hline Benzo(ghi)perylene & $\begin{array}{l}0.0056^{*} / \\
(0.01)\end{array}$ & $\begin{array}{l}0.0033^{*} / \\
(0.01)\end{array}$ & $0.0006 * /(0.01)$ \\
\hline PAH (sum10) & 1.9 & 1.1 & $0.2 * /(0.5)$ \\
\hline \multicolumn{4}{|l|}{ BTEX } \\
\hline Benzene & 0.94 & 0.27 & 0.2 \\
\hline Xylene & 0.94 & 0.27 & 0.2 \\
\hline Toluene & 4.7 & 1.4 & 1 \\
\hline Ethylbenzene & 4.7 & 1.4 & 1 \\
\hline \multicolumn{4}{|l|}{ Others } \\
\hline Phenols & 0.94 & 0.27 & 0.2 \\
\hline
\end{tabular}

Finally, some of the calculated EPC are below representative Limits of Quantifications (LOQ) for waste water at analytical laboratories. Particularly organic contaminants (PAH and VOX) were prone to this limitation, which would make it impossible to assess the concentrations in the landfill leachate. In order to overcome this problem, the derived emission criteria below the LOQ were replaced by policy decision by the representative LOQs (given between brackets in Table 1) in line with other regulatory frameworks on groundwater protection (Verschoor and Swartjes, 2008; Ministry of I\&E, 2013).

\section{Conclusions and outlook}

In order to prevent that future generations carry the responsibility for present day waste and to protect soil and groundwater quality sufficiently, a methodology was developed to derive site specific Environmental Protection Criteria (EPC) for three pilot landfills in the Netherlands in order to determine whether sustainable landfill management can be successful and achievable in due time.

These EPC are site-specific emission criteria that are expressed as maximum concentrations $(\mu \mathrm{g} / \mathrm{L})$ of designated contaminants in the landfill leachate. To derive the EPC several generic choices were made with respect to the conceptual model, environmental objectives and policy-related requirements that have been discussed in this paper. These choices are based on scientific knowledge, regulatory frameworks and their general acceptance, the current understanding of the selected pilot landfills and state-ofthe-art techniques for the modelling of leachate emissions to soil and groundwater. Site-specific information was preferred as much as possible, but to accommodate full acceptance of the methodology by the national government, the competent authorities and the general public, generic and often conservative policy-based assumptions were necessary.

During and at the end of the period of active treatment, monitoring of the concentrations in the landfill leachate takes place to monitor trends in leachate concentrations. This is done for the purpose of process evaluation and assessment of the final results. After the period of active treatment an evaluation period of at least 1 year is planned to determine the success of the experiment. A guideline is written which explains and determines how the final concentrations are assessed against the EPC. In this guideline, special attention is given to aspects such as monitoring frequencies, how to handle limiting detection limits during analysis, establishing average leachate concentrations and correction of the concentrations in accordance with the net infiltration during the evaluation period (Van der Gun, 2014).

Currently, actions are taken to start the period of active treatment of the three pilot landfills, which will take place for approximately 10-12 years. If after the experimental treatment period concentrations in the leachate of the landfills comply with the $\mathrm{EPC}$, the experiments are considered to be successful. In that case, national policy on landfills will then be amended to enable the use of sustainable landfill management at other eligible landfills in the Netherlands. It is than up to the landfill operators determine whether sustainable landfill management is economically feasible for further implementation.

The concepts used and knowledge gained in this experiment can be applied internationally. Similar landfills with similar aftercare problems are also in operation outside the Netherlands, and may benefit from the approach outlined in this paper. Caution should however be taken in using the modelled EPC presented in this paper directly for other landfills. Due to the site-specific model-input in the presented methodology, the modelled output (i.e. the EPC) might not be sufficiently protective or overprotective at other landfill sites. This applies especially for the case of ammonium, because of its relatively weak binding to soil and the (eutrophying) effects it can have when groundwater comes in direct 
contact with surface water. It is therefore recommended to derive dedicated EPC values for other sites using the described methodology.

Insights and assumptions may change over time as a result of increasing knowledge and changed perceptions of risks. Due to the ten-year experiment that will now take place at the pilot landfills it can be concluded that, shortly before the final success of the pilots is determined, the situation at the landfills should be compared with the assumptions and principles used to derive the EPC. If the conditions at the pilot landfills vary greatly from the assumptions and principles described in this paper, the methodology and as a result the EPC need to be reconsidered.

For a more detailed technical description of the geochemical modelling approach, modelling results and sensitivity analysis is referred to the paper of Dijkstra et al. (2016).

\section{Acknowledgements}

This work was enabled and funded by the Dutch Ministry of Infrastructure and Environment, Directorate-General for the Environment and International Affairs (Ministry of I\&M-DGMI). The authors would especially like to acknowledge Willem J. Kattenberg (chair of the project group Introduction of sustainable landfill management) for his devotion to enable this project.

\section{Appendix A. Supplementary material}

Supplementary data associated with this article can be found, in the online version, at http://dx.doi.org/10.1016/j.wasman.2016.07. 038.

\section{References}

Brand, E., De Nijs, A.C.M., Claessens, J.W., Dijkstra, J.J., Comans, R.N.J., Lieste, R., 2014 Development of Emission Testing Values to Assess Sustainable Landfil Management on Pilot Landfills. Phase 2: Proposals for Testing Values. National Institute for Public Health and the Environment (RIVM), Bilthoven, The Netherlands, Report no. 607710002.

Christensen, T.H., Kjeldsen, P., Albrechtsen, H.-J., Heron, G., Nielsen, P.H., Bjerg, P.L. Holm, P.E., 1994. Attenuation of landfill leachate pollutants in aquifers. Crit. Rev. Environ. Sci. Technol. 24, 119-202.

Christensen, T.H., Bjerg, P.L., Kjeldsen, P., 2000. Natural attenuation: a feasible approach to remediation of groundwater pollution at landfills. Ground Water Monit. Rem. 20, 69-77.

Dijkstra, J.J., Meeussen, J.C.L., Comans, R.N.J., 2004. Leaching of heavy metals from contaminated soils: an experimental and modelling study. Environ. Sci. Technol. 38, 4390-4395.

Dijkstra, J.J., Meeussen, J.C.L., Comans, R.N.J., 2009. Evaluation of a generic multisurface model for inorganic soil contaminants. Environ. Sci. Technol. 43, 61966201.

Dijkstra, J.J., Van Zomeren, A., Comans, R.N.J., Brand, E., Claessens, J.W., 2013a. Calculation site-specific emission criteria for sustainable landfills: the Dutch approach. In: Margherita di Pula, S. (Ed.), Proceedings Sardinia 2013, Fourteenth International Waste Management and Landfill Symposium, Cagliari, Italy; 30 September-4 October 2013. CISA Publisher, Italy.

Dijkstra, J.J., Van Zomeren, A., Susset, B., 2013b. Technical Principles Underlying Limit Values for Release of Substances for the Percolation Test TS3: Comparison DE and NL. ECN. The Netherlands and Consulting Office SiWap Bernd Susset, Germany, Report no. ECN-E-13-059.

Dijkstra, J.J., Van Zomeren, A., Comans, R.N.J., Brand, E., 2016. A novel approach in calculating site specific aftercare completion criteria for landfills in The Netherlands: geochemical modelling. (submitted for publication).

EC, 1999. Directive (1999/31/EC) of the European Parliament and of the Council on the landfill of waste. Off. J. Eur. Commun. L182.

EC, 2003. Directive (2003/33/EC) of the European Parliament and of the Council on establishing criteria and procedures for the acceptance of waste at landfills pursuant to Article 16 of and Annex II to Directive 1999/31/EC. Off. J. Eur. Commun. L11/27-49.

EC, 2006. Directive (2006/118/EC) of the European Parliament and of the Council on the protection of groundwater against pollution and deterioration. Off. J. Eur. Commun. L372/19.

EC, 2009. Guidance Document No. 18, Guidance on Groundwater Status and Trend Assessment Common Implementation Strategy for the Water Framework Directive (2000/60/EC). Directorate General Environment of the European Commission.
Hjelmar, O., Van der Sloot, H.A., Guyonnet, D., Rietra, R.P.J.J., Brun, A., Hall, D., 2001. In Development of acceptance criteria for landfilling of waste: an approach based on impact modelling and scenario calculations. In: Margarita di Pula, S. (Ed.), Proceedings Sardinia 2001, Eighth International Waste Management and Landfill Symposium, Cagliari, Italy; 1-5 October 2001. CISA Publisher, Italy.

Kattenberg, W.J., Heimovaara, T., 2011. In Policy process of allowing research pilots for sustainable emission reduction at landfills in The Netherlands. In: Margherita di Pula, S. (Ed.), Proceedings Sardinia 2011, Thirteenth International Waste Management and Landfill Symposium, Cagliari, Italy; 3-7 October 2011. CISA Publisher, Italy.

Kattenberg, W.J., Van der Sloot, H.A., Heimovaara, T.J., 2013. New Dutch legislation to allow research of natural biodegradation at landfills. In: Margherita di Pula, S. (Ed.), Proceedings Sardinia 2013, Fourteenth International Waste Management and Landfill Symposium, Cagliari, Italy; 30 September - 4 October 2013. CISA Publisher, Italy.

Laner, D., 2011. Understanding and Evaluating Long-term Environmental Risks from Landfills. Institute for Water Quality, Resources and Waste Management, Vienna University of Technology, Vienna.

Laner, D., Crest, M., Scharff, H., Morris, J.W.F., Barlaz, M.A., 2012a. A review of approaches for the long-term management of municipal solid waste landfills. Waste Manage. 32, 498-512.

Laner, D., Fellner, J., Brunner, P.H., 2012b. Site-specific criteria for the completion of landfill aftercare. Waste Manage. Res. 30, 88-99.

Meeussen, J.C.L., 2003. ORCHESTRA: an object-oriented framework for implementing chemical equilibrium models. Environ. Sci. Technol. 37, 11751182.

Miljøstyrelsen, 2003. Development of acceptance criteria for landfilling. Documentation of the Modelling and Scenario Calculations Carried out by DHI and ECN in Support of the Development of Acceptance Criteria for Landfilling within the TAC Subcommittee on the Landfill Directive (Draft, February).

Ministry of VROM, 1993. Implementation Directive to the Decree on Landfilling and Soil Protection. The Hague, The Netherlands. <http://wetten.overheid.nl/ BWBR0005877/2009-12-02/> (Last retrieved on 13/03/2016) (Dutch).

Ministry of VROM, 1997. Decree on Landfills and Bans on Landfilling of Waste. The Hague, The Netherlands. <http://wetten.overheid.nl/BWBR0009094/2013-07$01>$ (last retrieved on 13/03/2016) (Dutch).

Ministry of I\&E, 2011. Decree on Drinking Water. The Hague, The Netherlands. <http://wetten.overheid.nl/BWBR0030111/2015-11-28> (last retrieved on 13/ 03/2016) (Dutch).

Ministry of I\&E, 2013. Circular on Soil Remediation. The Hague, The Netherlands. <http://wetten.overheid.nl/BWBR0033592/2013-07-01> (last retrieved 13/03/ 2016) (Dutch)

Morris, J.W.F., Barlaz, M.A., 2010. A performance-based system for the long-term management of municipal waste landfills. Waste Manage. 31, 649-662.

Ritzkowski, M., Heyer, K.-U., Stegmann, R., 2006. Fundamental processes and implications during in situ aeration of old landfills. Waste Manage. 26, 356-372.

Reinhart, D., 1996. Full-scale experiences with leachate recirculating landfills: case studies. Waste Manage. Res. 14, 347-365.

Rich, C., Gronow, J., Voulvoulis, N., 2008. The potential for aeration of MSW landfills to accelerate completion. Waste Manage. 28, 1039-1048.

Susset, B., Grathwohl, P., 2010. Leaching standards for mineral recycling materials a harmonized regulatory concept for the upcoming German Recycling Decree. Waste Manage. 31, 201-214

Stegmann, R., Heyer, K.-U., Hupe, K., Willand, A., 2006. Landfill Aftercare - Options, Duration, Costs and Quantitative Criteria for Completion. Umweltbundesamt, Dessau, Germany (German).

Van der Gun, J.H.J. (red), 2014. Guide to Use Emission Target Values in the Context of Introduction Sustainable Landfill Management. Ministry of Infrastructure and Environment, The Hague, the Netherlands. <http://duurzaamstortbeheer.nl/wpcontent/uploads/2014/03/Handreiking-ETW-versie-11-eindrapport-dd.-10-012014.pdf > (last retrieved on 13/03/2016) (Dutch).

Van Vossen, W., Heyer, K., 2009. Feasibility Study Sustainable Emission Reduction at the Existing Landfills Kragge and Wieringermeer in The Netherlands. Royal Haskoning, s'Hertogenbosch, The Netherlands.

Verbruggen, E.M.J., Posthumus, R., van Wezel, A.P., 2001. Ecotoxicological Serious Risk Concentrations for Soil, Sediment and Water: Updated Proposals for First Series of Compounds. National Institute for Public Health and the Environment (RIVM), Bilthoven, The Netherlands, Report no. 711701020.

Verschoor, A.J., Lijzen, J.P.A., Van den Broek, H.H., Cleven, R.F.M.J., Comans, R.N.J., Dijkstra, J.J., Vermij, P., 2006. Critical Emission Values for Building Materials; Environmental Underpinnings and Implications for Building Materials. National Institute for Public Health and the Environment (RIVM), Bilthoven, The Netherlands, Report no. 711701043 (Dutch).

Verschoor, A.J., Lijzen, J.P.A., Van den Broek, H.H., Cleven, R.F.M.J., Comans, R.N.J., Dijkstra, J.J., 2008. Revision of the Dutch building materials decree: alternative emission limit values for inorganic components in granular building materials. In: The 9th International Symposium on Environmental Geotechnology and Global Sustainable Development, Hong Kong, June 1-4 2008.

Verschoor, A.J., Swartjes, F.A., 2008. Emissions to the Groundwater. Overview of Political Boundary Conditions and Assessment Procedures. National Institute for Public Health and the Environment (RIVM), Bilthoven, The Netherlands, Report no. 711701070 (Dutch). 


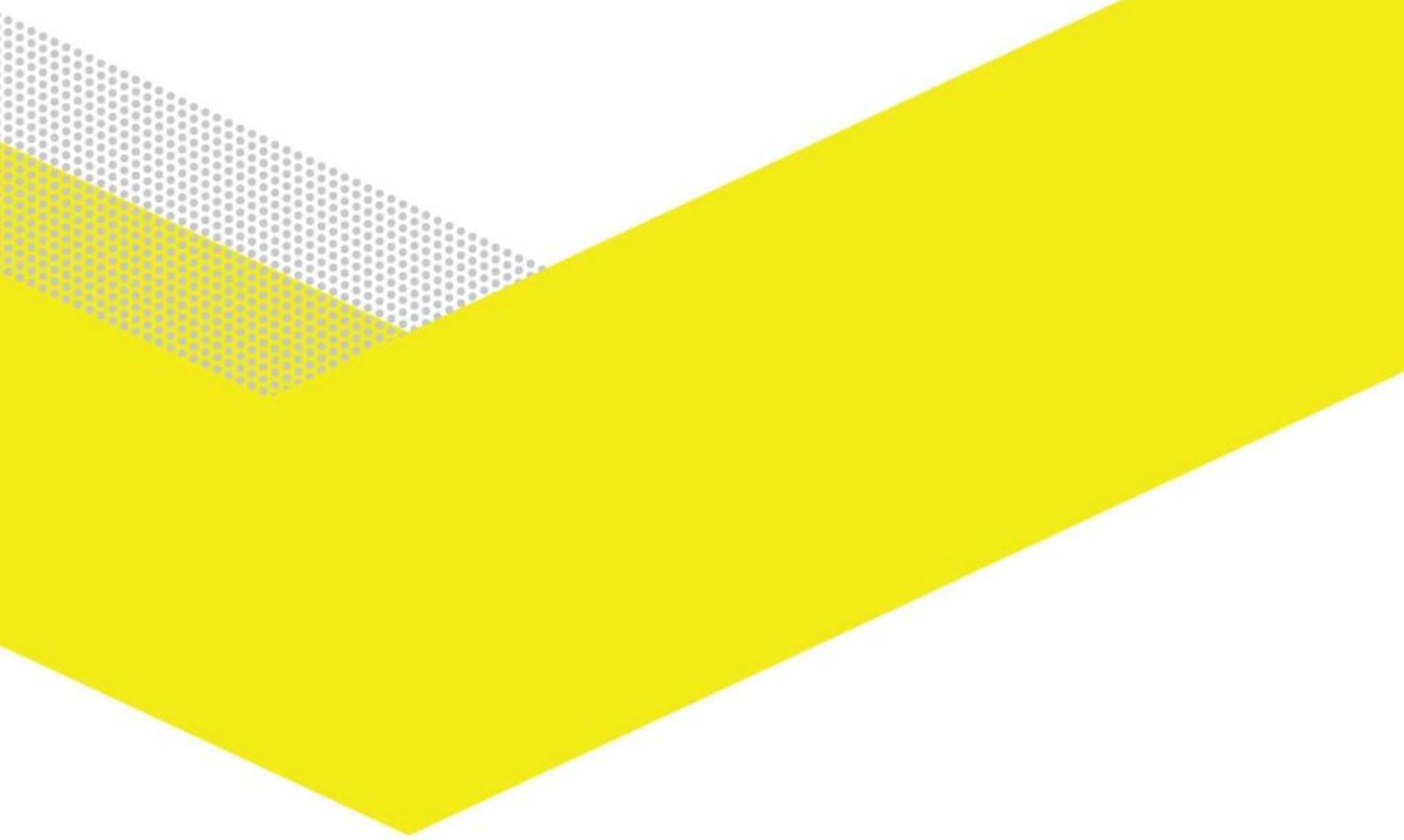

ECN

Westerduinweg $3 \quad$ Postbus 1

1755 LE Petten 1755 ZG Petten

T 0885154949

F 0885158338

info@ecn.nl

www.ecn.nl 